authors-we find that they rise in places to a level of between $7800 \mathrm{ft}$. and $8000 \mathrm{ft}$., whereas the highest level attained by the sediments near the Yellow. stone Falls is a little above $7800 \mathrm{ft}$. The lava surface stood, therefore, at a height sufficient to cause the filling of the upper end of the canyon to its very brim.

We turn now to a consideration of the longitudinal profile of the Yellowstone River and its principal tributaries. The Lamar Valley profile shows clearly three cycles of erosion-the earliest cycle is only represented by a portion near the head of the valley, the second cycle extends down to within about five miles of Junction Butte, where the valley of the third cycle begins. In the Yellowstone there are three or perhaps even four cycles represented (Fig. 5).

There is some doubt whether the part of the valley above the falls or the portion between the two falls should be assigned to the first cycle, but it is immaterial in this connexion. The main canyon belongs clearly to the second cycle and the third canyon to the third cycle, the second canyon being probably due to a later and postglacial cycle. The greater part of Tower Creek pertains to the second cycle, and at present hangs conspicuously above the second canyon. The profile of Broad Creek, which enters higher up the main canyon on the east side, is related as to its middle portion to the first cycle and as to its lower portion to the second cycle. Evidences of these cycles can also be traced in the transverse profiles of the various canyons. If now we project on to these profiles the outcrops of the basalt and trachytic rhyolite relics, we find that these descend at their lower ends to within about $\mathbf{1 0 0}$ feet of the river level in the third canyon and at their upper ends attain increasingly greater heights downstream.

It follows that these lava flows entered the canyon when the third cycle of erosion was far advanced.

Since the main canyon which pertains to the second cycle was eroded through the rhyolitic rocks it is obvious that a great interval of time separates the eruption of the rhyolites and that of the valley basalts which occupied the valleys of the third cycle. These considerations render it unthinkable that the basalts and conglomerates near Tower Falls were in existence prior to the eruption of the rhyolites. Moreover, there is reason to believe that the surface of the rhyolites had been reduced by prolonged erosion to a peneplain before the initiation of the first cycle of erosion. The canyon cycle of erosion thus commenced a very long time after the eruption of the rhyolites, and as a result, it is assumed, of successive uplifts, rejuvenation brought about the erosion of the main canyon and later of the third canyon. While the latter cycle was far advanced, eruptions of basalt and trachytic rhyolites dammed the canyon, and near the falls it was filled to the brim with sediments. Erosion was thus arrested and the canyon became a fossil canyon.

Since the lava eruptions of the Upper Pliocene the greater part of the lava dam has been removed, leaving only relics here and there as witnesses to the former extent of the lava floods. The erosion of the dam allowed of the removal of the sediments and the resurrection of the canyon. The original canyon is therefore an extremely ancient feature, dating probably from the Middle or Lower Pliocene.

In conclusion, it gives me great pleasure to put on record the remarkable accuracy of Mr. Holmes's observations and his deductions made during the short period when he was examining the geology and physical features of the Park more than fifty years ago.

\section{Mineral Industry of New South Wales.}

THHE Department of Mines of New South Wales has issued a very useful volume entitled "The Mineral Industry of New South Wales", written by E. C. Andrews and the staff of the Geological Survey, and edited by F. S. Mance, Under Secretary for Mines, who contributes two introductory sections. Such a work was long overdue; in 1901 a similar work, entitled "The Mineral Resources of New South Wales", was produced by Mr. Edward F. Pittman, at that time Government Geologist of New South Wales. This book contained a mass of useful information, and was in such demand that it has been out of print for many years. When Mr. Pittman's book was written, the most important mineral products of New South Wales were gold, copper, and tin, whereas to-day lead, zinc, and coal are of far greater importance.

The general trend of mineral production in the State has been markedly upwards, and the value of these productions has risen tremendously. The total value of the metals and minerals produced in the State of New South Wales to the end of 1927 is given as close upon 445 million pounds sterling, out of which the decade 1918-1927 has contributed no less than $155 \frac{1}{2}$ million pounds sterling, and there is every evidence that the upward trend is likely to continue.

The present work covers satisfactorily the whole field of mineral production; it commences with a few brief sections of a general character, followed by a description of the occurrences of metals and metallic ores, ranged in alphabetical order; the only serious exception to this statement may be found in the fact that the four metals, silver, lead, zinc, and cadmium, are all lumped together mainly for the reason that the ores of these metals are generally found intimately associated. Of course by far the most important deposit of these minerals in the State of New South Wales is in the Great Broken Hill deposit, one of the most important in the world, not only on account of its magnitude, but also because the intimate admixture of ores occurring there has stimulated the ingenuity of inventors to devise processes which have since been applied successfully to deposits in all parts of the world.

The third part of the book consists of a description of the occurrences of non-metallic minerals, also arranged in alphabetical order. The term 'non-metallic' minerals is used in its ordinary acceptance, compounds of the elements which the chemist would speak of as metals of the alkalis, and the alkaline earths being, in accordance with ordinary everyday usage, spoken of as non-metallic substances. The work is a very complete one, and will no doubt satisfactorily fulfil its object of presenting to the reader a brief but accurate and authoritative description of the mineral wealth of New South Wales.

\section{University and Educational Intelligence.}

Cambridge. - The Director of the Observatory has, with the consent of the Vice-Chancellor, reappointed Dr. W. M. Smart, of Trinity, as chief assistant at the Observatory for five years.

The Sudbury Hardyman. Prize at Emmanuel College, offered to a graduate of less than M.A. standing, has been awarded to $\mathrm{A}$. $\mathrm{H}$. Wilson for a dissertation on "Quantum Mechanics". Special dissertation prizes have been awarded to C. B. Allsopp (physical chemistry) and J. G. A. Griffiths (chemistry).

SIXTY-NINE ' land-grant' colleges and universities have been established in the United States under a series of Acts, beginning in the year 1862, for the granting of land for financing education in agriculture 
and the mechanic arts. The sixtieth annual report of the Bureau of Education on these institutions (Bulletin No. 14; 1928) shows that from small beginnings they have by degrees become leading factors in higher education, enrolling, as they do, more than two-fifths of all the university and college students in the United States. Land-grants now provide only a small fraction of their total revenues. In 1926-27 the land-grants and other federal aid amounted to only four million dollars out of receipts amounting in the aggregate to 137 million dollars. Twenty-six of them with receipts amounting to 78 million dollars are now combined land-grant colleges and State universities. Agriculture attracts only a small and diminishing number of students. In 1927 only seven and a half per cent of the resident students in the 52 institutions attended by white students were pursuing agricultural courses, while twenty per cent and five per cent were students of engineering and home economies respectively. In the 17 negro colleges, out of 7018 students enrolled in regular courses, 965 were studying agriculture, 1672 trades and mechanic arts, and 1630 home economics. A comprehensive national survey by the Bureau of Education of the land-grant colleges is now in progress.

THE annual conference of the Association of Teachers in Technical Institutions was held in Liverpool during the Whitsuntide holiday. In his presidential address, the new president, Mr. A. E. Evans, of the Battersea Polytechnic, pursued two main arguments which deserve special and serious attention, particularly in view of the educational reorganisation which is now proceeding. The first was that local and regional inquiries into the question of education and industry, and the setting up of occasional committees such as those for engineering and salesmanship, are not, in themselves, sufficient to solve the problems which have already received the attention of such national inquiries as those made by the Malcolm and Emmott Committees. Both these bodies saw the necessity of establishing a small national committee the duty of which would be to co-ordinate local and regional effort and to act as a clearing house for suggestions made towards the solution of the many problems now being presented. No concerted national action is possible without such a body, and, until it is set up, only piecemeal attempts at advance can be made. While welcoming the recently appointed committee on salesmanship, Mr. Evans insisted that production is the first necessity if our industrial problems are to be solved; new methods and new processes must be developed and devised, and new links made between the operations underlying production and the creation of power. Mr. Evans's second argument was one with which readers of NATURE are already familiar. In spite of the lip-service paid to the new conception of education with which our scientific and industrial civilisation is concerned, there is still a great tendency for educationists to regard with distrust schemes and curricula which deal with the application of science to industry, and to preserve, therefore, an attitude of remoteness from the everyday world. They forget, in their adoration of poets and artists and philosophers, the scientific workers, engineers, builders, and architects from whom technical institutions are handing down the means of lightening the burdens of mankind. Among resolutions dealt with by the Conference was one on the position of the junior technical school in the educational system. It was the result of a lengthy inquiry made by the Association which included special attention to the way in which these schools have been able to satisfy the demands of industrialists for employees able to adapt themselves to the changing needs of industry.

No. 3109 , VoL. 123]

\section{Calendar of Patent Records.}

June 1,1818 .- The first French aeronautical patent was that granted to P. C. Verger on June 1, 1818, for a dirigible airship. The ship, in the shape of a fish, was propelled by manually operated fans and was caused to rise or descend by a weight which could be moved along the length of the ship. According to the patent specification, successful flights had been made in which the airship had been driven and manœuvred with ease, but there is no other record of these flights. The ship bears a close resemblance to that proposed by Pauly and Egg, which had been patented in Great Britain three years earlier.

June 4, 1872.-Vaseline was patented in the United States by R. A. Chesebrough, of New York, on June 4, 1872, the word being used for the first time in the specification of this patent. It was decided in the British courts that the word became one descriptive of the substance on the lapse of the patent rights in Great Britain, and could not be registered as a trade-mark.

June 5, I787.-William Symington's steam engine, which was patented on June 5, 1787, was originally intended for a road carriage, but its chief claim to importance lies in the fact that it was used by Patrick Miller in the first practical attempts at steam navigation in Great Britain, a small double-hulled paddle boat, with the paddle wheels placed between the two hulls and originally driven by man power, being successfully propelled by it on Dalswinton Lake in 1788 . In the following year a larger vessel of the same type was propelled on the Forth and Clyde Canal at a speed of 5 miles an hour, but after a few trials the experiments were abandoned, and were not resumed until the Charlotte Dundas, with a new engine, was launched in 1803.

June 5, I 854.-James Bowman Lindsay was the first to propose a definite scheme for connecting Britain and America by wireless telegraphy. His invention for a method of transmitting telegraphic messages by electricity through and across water without submerged wires, the water being made available as the conducting medium, was patented on June 5, 1854. Signals were successfully transmitted across the River Tay (a distance of about $\frac{1}{2}$ mile), and Lindsay calculated that with two stations, one situated in Cornwall and one in Scotland, and two correspondingly disposed stations in America, communication could be obtained across the Atlantic.

June 7, I 821 .- The use of the rocket for the killing and capturing of whales was patented by Sir William Congreve and J. N. Colquhoun on June 7, 1821. The specification includes a description of the rocketbomb, which was afterwards re-invented in America and became one of the most deadly weapons used in whale-fishing.

June 9, I 840.--It was Thomas Edmondson who first thought of issuing railway tickets in their present form. His patent, dated June 9, 1840, had for its object the printing of "cardboard tickets in such a manner that each ticket should bear a progressive number or figure and thus, by being delivered in successive rotation to the passengers, the way bills would be readily made out, a most perfect check could be kept upon all clerks or other officers engaged in receiving money, and a daily or weekly return could be readily made merely by noting the opening and closing numbers of the tickets delivered ". The invention comprised a printing machine for printing the cardboard blanks with the proper letterpress and successive numbers, and a dating machine which was put into operation by pushing the end of the ticket into the apparatus. 